\title{
"Social responsibility as a factor in ensuring the competitiveness of a business
}

organization"

\begin{tabular}{|c|c|}
\hline AUTHORS & $\begin{array}{l}\text { Taras Kytsak E https://orcid.org/0000-0002-0525-7556 } \\
\mathbb{R} \text { http://www.researcherid.com/rid/K-7699-2018 }\end{array}$ \\
\hline ARTICLE INFO & $\begin{array}{l}\text { Taras Kytsak (2018). Social responsibility as a factor in ensuring the } \\
\text { competitiveness of a business organization. Social and labour relations: theory } \\
\text { and practice, } 8(2), 27-34 \text {. doi:10.21511/sIrtp.8(2).2018.03 }\end{array}$ \\
\hline DOI & http://dx.doi.org/10.21511/slrtp.8(2).2018.03 \\
\hline RELEASED ON & Friday, 01 March 2019 \\
\hline RECEIVED ON & Monday, 12 November 2018 \\
\hline \multirow[t]{2}{*}{ ACCEPTED ON } & Thursday, 20 December 2018 \\
\hline & $($ (c) EY \\
\hline LICENSE & $\begin{array}{l}\text { This work is licensed under a Creative Commons Attribution } 4.0 \text { International } \\
\text { License }\end{array}$ \\
\hline JOURNAL & "Social and labour relations: theory and practice" \\
\hline ISSN PRINT & $2410-4752$ \\
\hline ISSN ONLINE & $2415-3389$ \\
\hline PUBLISHER & LLC "Consulting Publishing Company "Business Perspectives" \\
\hline FOUNDER & $\begin{array}{l}\text { State Higher Educational Establishment "Kyiv National Economic University } \\
\text { named after Vadym Hetman", Social and Labour Relations Institute }\end{array}$ \\
\hline
\end{tabular}

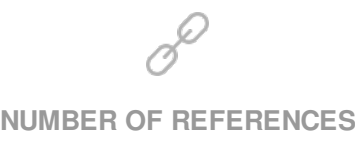

10

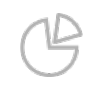

NUMBER OF FIGURES

1

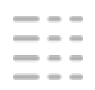

NUMBER OF TABLES

2

(C) The author(s) 2023. This publication is an open access article. 


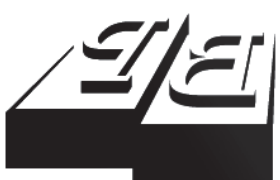

BUSINESS PERSPECTIVES

Publisher

LLC "CPC "Business Perspectives" Hryhorii Skovoroda lane, 10, Sumy, 40022, Ukraine www.businessperspectives.org

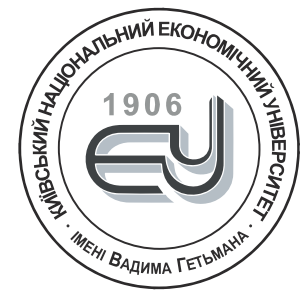

\section{HETMAN KNEU}

Founder

State Higher Educational Establishment "Kyiv National Economic University named after Vadym Hetman",

Prospect Peremogy, 54/1,

Kyiv, 03057, Ukraine

https://kneu.edu.ua/

Received on: 12th of

November, 2018

Accepted on: 20th of

December, 2018

(C) Taras Kitsak, 2018

Taras Kitsak, Ph.D. in Economics, Associate Professor, Personnel Management and Labor Economics Department, Kyiv National Economic University named after Vadym Hetman, Ukraine.
SOCIAL RESPONSIBILITY AS A FACTOR IN ENSURING THE COMPETITIVENESS OF

\section{A BUSINESS ORGANIZATION}

\begin{abstract}
The article investigates manifestations, trends and dominants of the concept of social responsibility of business; its impact on balanced social development has been determined. The active role of social responsibility in ensuring the stability and competitiveness of business processes has been substantiated. The aim of the research is to determine the impact of socially responsible practices on the socioeconomic development of a business organization in modern conditions. The author determined his own interpretation of corporate social responsibility after having researched its essence and its impact on social and business processes.

The list of potential benefits for a business organization from realization of social investments has been specified and supplemented. The content and essence of the construct of a socially responsible organization which focuses on the development and successful functioning in a dynamic market environment have been distinguished. The sphere of interaction of the business organization with the main stakeholders has been analyzed and potential directions of establishing a constructive dialogue that will have a positive impact on the stability and success of business processes have been outlined. Sociological research on the evaluation of the perception of social responsibility by business organizations in Ukraine and awareness of its values, trends and benefits has been analyzed. Conclusions regarding directions of strengthening of forming the environment of facilitating the spreading of the concept of corporate social responsibility have been justified.
\end{abstract}

Keywords

JEL Classification corporate social responsibility, stakeholders, balanced social development, socially responsible practices, social investments, social reporting
Т.Г. Кицак (Україна)

\section{СОЦІАЛЬНА ВІДПОВІДАЛЬНІСТЬ ЯК ФАКТОР ЗАБЕЗПЕЧЕННЯ КОНКУРЕНТОСПРОМОЖНОСТІ БІЗНЕС-ОРГАНІЗАЦІї}

\begin{abstract}
Анотація
У статті досліджено прояви, тренди та домінанти концепції соціальної відповідальності бізнесу, визначено ii вплив на збалансований суспільний розвиток. Обгрунтовано активну роль соціальної відповідальності у забезпеченні стійкості та конкурентоспроможності бізнеспроцесів. Метою дослідження $є$ встановлення впливу соціально відповідальних практик на соціально-економічний розвиток бізнес-організації в сучасних умовах. В процесі дослідження теоретичних підходів щодо розуміння сутності соціальної відповідальності бізнесу визначено власне трактування сутності цього концепту, його вплив на суспільні та бізнесові процеси. Уточнено і доповнено перелік потенційних зисків для бізнес-організації від реалізації соціальних інвестицій. Виокремлено яким має бути за змістом і сутністю конструкт соціально відповідальної організації що орієнтується на розвиток та успішне функціонування у динамічному ринковому середовищі. Проаналізовано сферу взаємодії бізнесової-організації з головними стейкхолдерами та окреслено потенційні напрями налагодження конструктивного діалогу що матиме позитивний вплив на стійкість та успішність бізнесових процесів.
\end{abstract}


Проведено аналіз соціологічного дослідження на предмет сприйняття бізнесовими організаціями в Україні сутності соціальної відповідальності та усвідомлення іiі цінностей, трендів та переваг. Обгрунтовано висновки стосовно напрямів формування позитивного середовища поширення концепту корпоративної соціальної відповідальності.

Ключові слова

корпоративна соціальна відповідальність, стейкхолдери, збалансований суспільний розвиток, соціально відповідальні практики, соціальні інвестиції, соціальна звітність

Класифікація JEL A13, L14, M14

\section{ВСТУП}

Соціально-економічна стабільність і ощадливе використання ресурсів навколишнього середовища являються головними засадами збалансованого розвитку більшості розвинених країн. Ці фактори формують ряд вимог до бізнес-організацій як головних суб’єктів впливу на соціальні, економічні та екологічні сфери життєдіяльності суспільства. Такі глобальні виклики спонукають бізнес до пошуку нових способів раціонального поєднання забезпечення максимального рівня прибутковості та задоволення запитів та потреб головних груп стейкхолдерів. Дієвим інструментом досягнення цих цілей $є$ впровадження в практику господарської діяльності концепції корпоративної соціальної відповідальності.

\section{1. ЛІТЕРАТУРНИЙ ОГЛЯА}

Аналізуючи літературні джерела можна переконатися у тому, що наукова спільнота надає вагоме значення концепту корпоративної соціальної відповідальності як фактору, який активним чином впливає на забезпечення умов збалансованого суспільного розвитку. Ці переконання підтверджуються рядом практичних проявів, які мають результуючі підсумки як у дослідженнях можливостей забезпечення стійкості бізнес-процесів, так і в розвідках стосовно того, як суспільство може забезпечити свої головні потреби від налагодження партнерської взаємодій держави, бізнесу та інститутів громадянського суспільства. Відомі науковцідосліджують феномен соціальної відповідальності в контекстіуправлінського та соціоекономічного прояву, а також разом з іншими спорідненими теоретичними конструкціями, які виникли в результаті його впливу на різноманітні сфери як бізнесового так і суспільного життя. До таких конструкцій належать концепції корпоративної стійкості, корпоративного громадянства, заінтересованих сторін та деякі інші.

У науковій літературі вперше зустрічається інформація про актуальність соціальної відповідальності бізнесових-організацій у 1889 році в трактатах Карнегі під назвою «Євангеліє багатства». В своїх дослідженнях автор пропагує розуміння концепції соціальної відповідальності бізнесу як прояв благодійництва та доброчинності. У майбутньому його ідеї сформували базове підгрунтя для розвитку багатьох наукових підходів щодо визначення сутності, принципів та головних засад корпоративної соціальної відповідальності. Він акцентував увагу на тому, що добробут суспільства може мати свої реальні прояви тільки тоді, коли бізнес-організації будуть здійснювати вагомий внесок у його поліпшення. В основі благодійництва та доброчинності він вбачав допомогу успішних та заможних громадян людям, які мають скруту та реально потребують допомоги [3].

Концепт соціальної відповідальності бізнесу досліджували такі відомі зарубіжні вчені-економісти, як: Акерлоф, Боуен, Друкер, Девіс, Котлер, Керрол, Фрідман, Пост, Сігель та інші.

Вагомий внесок у розуміння концептуальної сутності соціальної відповідальності, розробку категоріального апарату та науковому обгрунтовані думки про те, що соціальна відповідальність має всі ознаки соціального інституту, здійснив американський учений Боуен, видавши у 1953 році монографію «Соціальна відповідальність бізнесмена». В цьому творі було висвітлено головні домінанти, тренди та засади соціально відповідальних практик, окреслено напрями поширення та удосконалення феномену соціальної відповідальності. I в майбутньому це сприяло популяризації ідеї про те, що Боуен може по праву мати статус фундатора корпоративної соціальної відповідальності. Але були науковці, які мали 
інше визначення сутності соціальної відповідальності бізнес-організації. Вони, в свою чергу, з іншого кута зору, іншими підходами визначали якісне наповнення цієї концепції, але більшість 3 них, все таки, за основу використовували ідею, яку означив Боуен. Згідно якої, соціальна відповідальність бізнесорганізації має реалізовуватись у господарських практиках орієнтованих на задоволення головних запитів, потреб та інтересів суспільства.

На початку 1970-х інший американський вчений Фрідман запропонував нове визначення КСВ, сутність якого полягала у тому, що бізнес-структура має здійснювати свою діяльність у межах законодавчих норм, етичних правил, але головним ї̈ завданням має бути отримання прибутку [8]. Фрідман також висловлював переконання про те, що бізнес не має зобов’язань перед суспільством, а ці функції має виконувати лише персонал компаній. В нинішніх реаліях, незважаючи на те, що ідеї Боуена та інших дослідників цього концепту мають прогресивну та гуманістичну спрямованість $€$ багато бізнес-організацій, які наслідують Фрідмана.

Значний вклад у становлення концепту корпоративної соціальної відповідальності привніс інший представник когорти американських учених Девіс, котрий на протязі тривалого часу очолював Академію менеджменту. Весь цикл його праць був присвячений розвитку базових теоретичних засад концепту соціальної відповідальності бізнесу та впливу на бізнес-процеси, аргументувавши його доцільність зисками стійкості та забезпечення конкурентоспроможності бізнес-процесів. В основі його бачення ефективних бізнес-практик $є$ міркування про те, що компанії мають будувати політику плідної взаємодії з головними зацікавленими сторонами, серед яких виокремлюються на першому місці споживачі, персонал, інвестори, представники територіальних громад. В процесі взаємовідносин мають бути забезпечені не тільки економічні, соціальні, екологічні запити, але й також морально-духовні, політичні та інші очікування [5].

3 поширенням глобалізації посилюється вплив соціуму на бізнес-процеси, оскільки інтернаціоналізація економічних відносин, залучення до виробничих процесів суб'єктів, які являються носіями різних культурних цінностей, потребує налагодження тісних та стійких соціальних контактів для забезпечення успішного функціонування та розвитку бізнесових практик. Тому, наразі, реалізовувати певні підприємницькі ідеї та досягати мети з використанням усталених правил і процедур недостатньо для забезпечення позитивного іміджу, актуального бренду, посилення конкурентоспроможності та формування стійкості бізнесових процесів. Соціальна відповідальність являється універсальним соціально-економічним інститутом забезпечення адекватної відповіді на запити зовнішнього та внутрішнього середовища, дієвим ресурсом укріплення бізнесових позицій.

Керівник відомої в Україні наукової школи з управління персоналом та економіки праці Колот висловив ідею про те, що бізнес-організаціїмають активніше втілювати в управлінськіпроцеси принципи соціальної відповідальності, які за своєю суттю у найзагальнішому, «приземленому» тлумаченні розуміються як система економічних, соціальних, екологічних заходів, а також етичних норм і цінностей компанії, які в сукупності забезпечують суспільну корисність її діяльності, реалізуються на основі постійної взаємодії із заінтересованими сторонами (стейкхолдерами) і спрямовані на зменшення нефінансових ризиків, довгострокове поліпшення іміджу і ділової репутації компанії, а також на набуття конкурентних переваг і стратегічної стійкості бізнес-організації [9]. Актуальність цих думок також підтверджуються міркуваннями ще одного американського вченого австрійського походження Друкера, який у своїх наукових працях пропагував ідею доцільності поєднання економічного прогресу і соціальної гармонії. Свої бачення він узагальнив такими словами: «Не існує ніякого внутрішнього протиріччя між прибутком і необхідністю для компанії приносити суспільну користь - більше того, перше $є$ необхідним для того, щоб досягати наступного... Компанія, яка не враховує свій вплив на суспільство і свою відповідальність перед ним, може отримати справедливе невдоволення з боку суспільства ... Протест проти «суспільства споживання» і боротьба за екологію - це не вороги економіки, це симптоми того, що бізнес повинен усвідомлювати свою важливу соціальну роль» [6].

У 1991 році Керрол, теж представник американського наукового співтовариства, висловив досить 
прагматичний тезис стосовно розуміння сутності КСВ основу якого формує уявлення про те, що «двигуном» всіх позитивних суспільних процесів може бути виключно забезпечення економічного інтересу господарюючого суб’єкту. Він це підтверджує тим, що підвалини його концепту становлять основні чотири елементи: економічна, правова, етична та філантропічна відповідальність, які можна представити у вигляді піраміди на Рисунку 1. Базис піраміди формує економічна відповідальність, яка на думку Керрола являється головною функцією бізнес-організації на ринку як суб’єкту поширення товарів та послуг. Він стверджував що тільки досягнення бізнесових цілей сприятиме забезпеченню потреб та інтересів суспільних. Правова ж відповідальність передбачає дотримання законодавства в процесі господарської діяльності, орієнтування на інтереси та очікування суспільства, зафіксовані в правових нормах. Етична відповідальність має прояв у дотриманні існуючих норм моралі та відповідальної поведінки. Відповідальність філантропічна має свій практичний прояв у вигляді добровільної участі бізнесових структур у здійсненні соціальних інвестицій. Щодо цієї моделі, то у науковому співтоваристві існує багато негативних відгуків щодо доцільності такого трактування базових засад корпоративної соціальної відповідальності. Ці суперечності викликані економічною прерогативою соціальних процесів, яку сповідують прихильники цієї концепції, а також тим, що вона у спрощеному вигляді показує багатогранний прояв та різноаспектні впливи сутності соціальної відповідальності на бізнесову та суспільну діяльність. Але якщо брати до уваги глобальне поширення асиметрії економічної та соціальної сфери, то модель Керрола має свою цінність при характеризуванні поведінки багатьох бізнесових структур, які поширюють соціальну відповідальність як засіб активного використання власних ресурсів в діях, орієнтованих виключно на збільшення прибутку.

Представники іншого континенту, зокрема, Європейське співтовариство висловлює думку про цінність корпоративної соціальної відповідальності тезисом Європейської Комісії, який трактує її наступним чином: «КСВ - це концепція, згідно з якою компанії на добровільній основі інтегрують соціальні та екологічні проблеми в своїй діяльності і у взаємодії із зацікавленими сторонами» [7]. Але попри таке лояльне визначення сутності європейська модель характеризується регулюванням цієї сфери за допомогою активного використання норм, стандартів та законів відповідних держав.

Результатом аналізу теоретичних підходів до визначення сутності такого важливого соціального та економічного інституту як корпоративна соціальна відповідальність, $є$ авторське її трактування - це

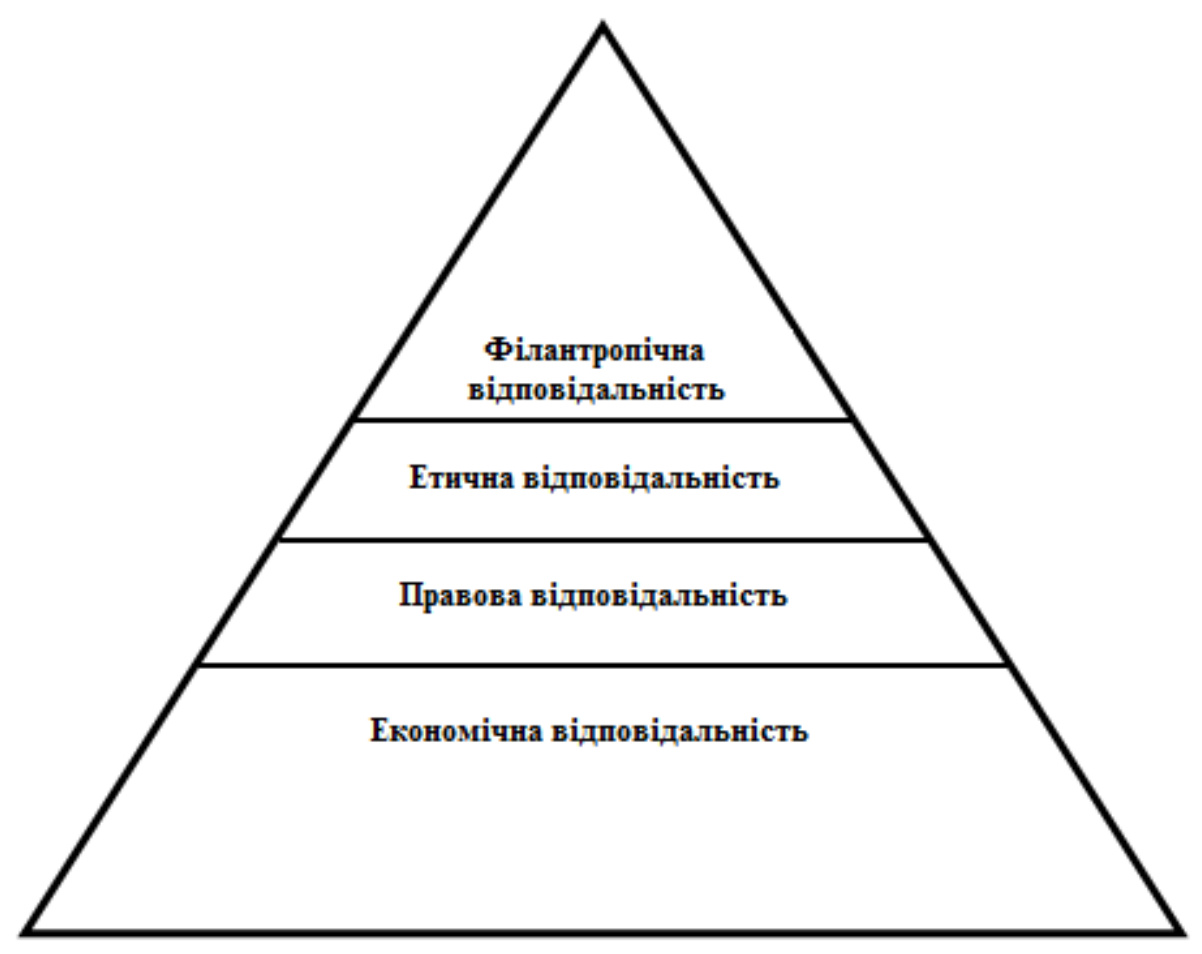

Рисунок 1. Піраміда корпоративної соціальної відповідальності [4]. 
процеси, які відбуваються за певною системою цінностей, принципів, правил, які позитивно впливають

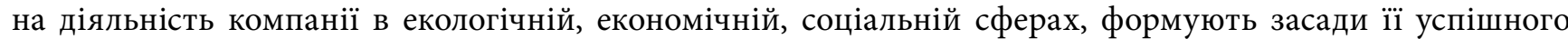
розвитку та створюють передумови для ефективного функціонування національної економіки.

\section{META}

Метою цією роботи є обгрунтування впливу соціально відповідальних практик на посилення конкурентоспроможності, формування іміджу та бренду бізнес-організації.

\section{3. РЕЗУЛЬТАТИ}

У 50-х роках минулого століття великі корпорації і середній бізнес прийшли до розуміння того, що бути соціально відповідальними в сучасному світі вигідно - підвищується капіталізація, зміцнюється конкурентоспроможність, стійкість і інвестиційна привабливість бізнесу. За останні 10-15 років соціальна відповідальність бізнесу як фактор сприяння збалансованому суспільному розвитку в розвинених економіках країн Північної Америки та Європейського Союзу постала інноваційним трендом для бізнесспівтовариства, запорукою соціально-партнерських контактів з органами державної влади всіх рівнів $\mathrm{i}$ громадянським суспільством. Що дозволяє компаніям мати ефективний результат як мінімум у формі:

- поліпшення бренду, іміджу та ділової репутації;

- зростання капіталізації;

- посилення згуртованості персоналу та підвищення продуктивності праці;

- поліпшення прозорості бізнес-організації для громадськості;

- покращення інвестиційної привабливості;

- зростання внеску у процес формування збалансованого суспільного розвитку.

Проведені дослідження споживчого попиту у США в 2014 році показали результати про те, що 84\% опитаних переважно довіряють компаніям, які здійснюють внески в різні соціально-благодійні справи, тобто, проявляють певний рівень соціальної відповідальності. Приблизно 90\% готові змінити свої уподобання відносно обраної ними компанії, якщо інша буде відрізнятись соціальними ініціативами, цінними для споживачів.

Представниками Гарвардської школи бізнесу було проведено масштабне дослідження, в ході якого було з'ясовано, що ті бізнес-організації, які практикують у своїй діяльності соціальні програми, перевершують за всіма істотними показниками організації, які такі практики ігнорують. Також в ході дослідження було виявлено, що згідно з даними коефіцієнта рентабельності USD 1, інвестований у 1994 році в соціальну діяльність, підвищив цей показник до 2010 року до рівня USD 7. У той же час як USD 1, інвестований в бізнес-організацію, яка не практикує соціальну активність, спряв підвищенню капіталізації лише до USD 4. Що наглядно демонструє факт актуальності соціальної відповідальності у процесі забезпечення стратегічної стійкості, ефективного функціонування та розвитку бізнес-організації [1].

Соціально відповідальна діяльність - процес надзвичайно чутливий і складний, що зобов’язує компанію істотно перебудовувати генеральну стратегію, місію, філософію діяльності. Крім того необхідно залучати до управлінських процесів фахівців, які володіють необхідними компетенціями з формування корпоративної інформаційної політики, налагодження тісної взаємодії з головними стейкхолдерами, імплементації принципів КСВ у організаційну структуру компанії, підготовки та популяризації соціальної звітності, проведення переговорів і обмін досвідом на європейському та національному рівнях, презентації бізнес-організації за кордоном.

У 2018 році Центром «Розвиток КСВ» в рамках проекту «Розбудова потенціалу Національного контактного пункту з відповідальної бізнес-поведінки» за підтримки Посольства Королівства Нідерландів в Україні 
було проведено дослідження на предмет усвідомлення бізнесовими колами сутності на напрямів прояву корпоративної соціальної відповідальності. Проведеним дослідженням було охоплено 400 бізнес-організацій.

Результати дослідження стосовно спонукальних мотивів з реалізації бізнес-організаціями практик соціальної відповідальності представлені у Таблиці 1.

Таблиця 1. Мотиви реалізації практик соціальної відповідальності бізнес-організаціями

Джерело: Складено на основі [10].

\begin{tabular}{l} 
Чому ваша компанія реалізує практики соціальної відповідальності? \\
\hline Відповіді \\
\hline з моральних міркувань \\
Це покращує репутацію компанії \\
Це сприяє підвиенню лояльності персоналу \\
Це допомагає впровадженню інновацій \\
Це сприяє збільшенню продажів
\end{tabular}

Як показали результати опитування бізнес-суб’єктів, моральні міркування є головними мотиваторами впровадження політик соціальної відповідальності, що свідчить про недостатнє усвідомлення потенційних позитивних наслідків цього потужного соціально-економічного інституту для посилення конкурентоспроможності, покращення репутації, бренду та іміджу. Ці факти можуть бути пояснені тим, що бізнес-організації приймають участь у вирішенні соціально-економічних проблем, спровокованих анексією Криму та конфліктом на Сході України. Такі висновки підтверджуються результатами опитування, оскільки третя частина учасників розуміє КСВ як прояв соціальної допомоги учасникам АТО та мешканцям цієї зони.

Результати дослідження про уявлення бізнес-організацій щодо напрямів реалізації соціально відповідальних практик представлені у Таблиці 2.

Таблиця 2. Напрями реалізації соціально відповідальних практик бізнес-організаціями

Джерело: Складено на основі [10]

\begin{tabular}{|c|c|c|c|c|c|}
\hline \multirow{2}{*}{ Напрями реалізації } & \multicolumn{5}{|c|}{ Відповіді за регіонами, \% } \\
\hline & Північ & Захід & Центр & Схід & Південь \\
\hline Розвиток і поліпшення умов праці & 82 & 69 & 67 & 74 & 77 \\
\hline Інвестиції в розвиток регіону & 34 & 29 & 30 & 40 & 30 \\
\hline Захист і підтримка споживачів & 38 & 29 & 35 & 34 & 26 \\
\hline Здійснення екологічних проектів & 33 & 21 & 22 & 31 & 14 \\
\hline Благодійна допомога & 30 & 26 & 17 & 36 & 19 \\
\hline Допомога воїнам АТО та мешканцям зони АТО & 34 & 25 & 22 & 35 & 16 \\
\hline Здійснення екологічних проектів & 33 & 21 & 22 & 31 & 14 \\
\hline Допомога переселенцям & 26 & 18 & 19 & 28 & 12 \\
\hline Участь у розробці рефрорм та законів & 37 & 20 & 20 & 29 & 12 \\
\hline Боротьба з корупцією & 28 & 18 & 13 & 33 & 10 \\
\hline
\end{tabular}

Як показали ці результати, компанії усвідомлюють важливість налагодження якісної взаємодії 3 головним внутрішнім стейкхолдером - персоналом. Бізнес-організації осмислюють актуальність основних ідей соціальної відповідальності у напрямі формування сприятливих умов плідної взаємодії 
працівників і менеджменту компанії. Ці фактори підтверджуються досвідом провідних світових компаній, у яких люди і їх таланти перетворюються в найбільш цінні ресурси, а ознаки гідної праці приносять відчутні економічні зиски. Практики соціальної відповідальності в цьому аспекті сприяють залученню компетентних, цікавих, яскравих та неординарних особистостей, що, в свою чергу, впливає на підвищення продуктивності праці, посилення ініціативності і раціоналізаторства, а також інноваційного, науково-технологічного розвитку виробничих процесів.

Загалом, налагодження ефективної взаємодії з основними групами стейкхолдерів, як зовнішніми так і внутрішніми, сприяє результативному і стійкому розвитку бізнес-організації; забезпечує краще управління ризиками та репутацією; дозволяє об’єднувати ресурси (знання, персонал, гроші і технології) для вирішення проблем і досягнення цілей, які не можуть бути досягнуті організацією наодинці; допомагає комплексно оцінити зовнішнє середовище бізнесу, включаючи розвиток ринкового сегменту i визначення нових стратегічних можливостей; сприяє удосконаленню корпоративного продукту i корпоративних бізнес-процесів. В основі побудови ефективної політики взаємодії зі стейкхолдерами має бути дослідження та оцінка їх інтересів, потреб, цінностей, а також організація результативних відповідей на ці запити. Тоді, в свою чергу, соціально відповідальна поведінка сприятиме стійкості бізнесових процесів та буде запорукою довгострокового процвітання компанії. Бізнес-організації, що не реалізуватимуть політику соціальної відповідальності, втрачатимуть можливості, конкурентні переваги, відставатимуть в організації якісного управління персоналом. Не використовуючи цей потужний соціально-економічний інститут, компанії не діагностуватимуть вплив власних виробничих процесів на суспільство та природнє середовище, що в майбутньому може сприяти виникненню певних ризиків відносно успішності господарської діяльності. Результативні практики у сфері соціальної відповідальності являтимуть собою позитивний фактор залучення інвестицій, посиленням якості взаємодії з постачальниками, споживачами, територіальними громадами, органами державної влади, засобами масової інформації.

\section{ВИСНОВКИ}

Проаналізувавши сучасні наукові підходи щодо сутності концепту корпоративної соціальної відповідальності та дослідивши результати вітчизняних бізнес-практик, приходимо до висновку, що українському бізнес-середовищу необхідно активніше втілювати у повсякденну господарську практику цінності та принципи соціальної відповідальності як динамічного фактору забезпечення конкурентоспроможності, підвищення капіталізації, інноваційного розвитку бренду, удосконалення корпоративної культури, гармонії взаємовідносин з головними групами стейкхолдерів. Реалізація соціально відповідальних ініціатив матиме великусинергетичну дію, яка спрятиме досягненню головних цілей і мети бізнесових організацій а також забезпечуватиме головні запити суспільства. Активна популяризація ідеї соціальної відповідальності бізнесу з боку науковців, просвітницька діяльність у цій царині може і повинна поєднуватися з елементами прямого та опосередкованого впливу на діяльність бізнес-організацій з боку держави, як соціального інституту, який має стимулювати діяльність компаній в інтересах суспільства. Соціальні інвестиції мають стати наріжним каменем, навколо чого формуватиметься імідж і репутація сучасного бізнесу, оскільки вони являються ефективним інструментом вирішення соціальних проблем і їх спрямованість має бути орієнтована на ефективний $\mathrm{i}$ інноваційний соціально-економічний розвиток.

\section{СПИСОК ЛІТЕРАТУРИ}

1. Belyaeva, I. Y. (2013). Корпоративная социальная ответственность: управленческий аспект [Korporativnaya sotsialnaya otvetstvennost: upravlencheskiy aspekt]. Moscow: KNORUS.

2. Bowen, H. (1953). Social responsibilities of the businessman. N.Y.: Harper \& Row.

3. Carnegie, A. (2012). The gospel of wealth. Revija za socijalnu politiku, 19(2), 199-206. 
4. Carroll, A. B. (1991). The pyramid of corporate social responsibility: toward the moral management of organizational stakeholders. Business horizons, 34(4), 43.

5. Davis, K. (1967). Understanding the social responsibility puzzle: what does the businessman owe to society. Business horizons, 10(4), 46-47.

6. Druker, P. (2012). Менеджмент. Вызовы XXI века [Menedzhment. Vyzovy XXI veka]. Moscow: Mann, Ivanov i Ferber.

7. European Commission (2010). Sustainable and responsible business. Corporate social responsibility (CSR). Retrieved from http://ec.europa. eu/enterprise/policies/sustainable-business/corporate-socialresponsibility/index_en.htm

8. Friedman, M. (1970). The social responsibility of business is to increase its profits. New York Times magazine, 13, 32-33.

9. Kolot, A. M. (2013). Corporate social responsibility and the public perception of the problem. Sotsialno-trudovi vidnosyny: teoriia i praktyka, 2(6), 6-16.

10. Zinchenko, A., \& Saprykina, M. (2017). CSR development in Ukraine: 2010-2018 (52 p.). Kyiv: Printing house "Yuston». Retrieved from http://csr-ua.info/csr-ukraine/wp-content/uploads/2018/10/CSR_2017_reserch_en.pdf 